\title{
DEPARTMENT OF SCIENTIFIC AND INDUSTRIAL RESEARCH
}

\author{
ANNUAL REPORT FOR $1954-55$
}

$\mathrm{T}$ HE annual report of the Department of Scientific and Industrial Research for the year 1954-55* includes the report of the Committee of the Privy Council for the year ended September 30, 1955, over Lord Salisbury's signature, and the fortieth report of the Advisory Council, signed by Sir Hugh Beaver, which gives the usual summary of work carried out by the various research stations and boards and research associations. Besides the summary of the Department's expenditure for the year ended March 31, 1955, there are appended lists of assessors to the Advisory Council, of the various committees of the Advisory Council, of research boards of the Department and their membership, of grants for special researches in progress or authorized during the year, of students awarded maintenance allowances for postgraduate training in research and a 49 -page list of publications issued during the year. The Advisory Council can fairly claim at the outset that the Summary of Work and Appendixes afford a valuable means of obtaining easily detailed information regarding the work of the Department in widely varying fields; but the question as to whether the present organization is adequate to deal efficiently with matters of public relations remains to be determined. The persistence and the character of Parliamentary questions suggest that the problem is not yet solved, and it is improbable that an annual report of this type can contribute greatly to a solution.

The gross expenditure of $\$ 6,685,400$ compares with $£ 5,865,279$ in the previous year and is reduced to $£ 5,898,016$ net by various receipts ( $£ 370,536$ being from the National Physical Laboratory) for work done for government departments or for industry, the net increase on $1953-54$ being $£ 643,674$; the estimates for 1955-56 provide for a further increase of $£ 630,154$, and those of $1956-57$ for a net increase

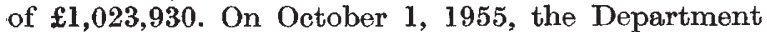
employed 4,379 staff of all grades (including 190 part-time) compared with 4,220 (164 part-time) in the previous year. Annual grants to research associations totalled $£ 1,335,125$ (compared with $£ 1,254,088$ in $1953-54$ ), grants for special researches amounting to $£ 315,425$ ( $£ 412,431$ in $1953-54)$. Grants to students amounted to $£ 323,022$, an increase of

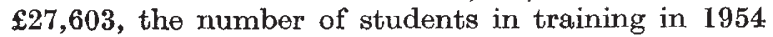
being 1,052 , and in $1955,1,022$, compared with 1,009 in 1953; and of these, 381 in 1954 and 379 in 1955 were new. Of eight senior research awards in 1954 and in 1955 , two in 1954 and five in 1955 were new, and 26 new grants for special researches in 1954 and 15 in 1955 brought the total of such grants to 64 and 53, respectively, compared with 58 in 1953 and 70 in 1952. Of the grants for special researches, 37 in 1954 and 33 in 1955 were in physics ; for chemistry the figures were 9 and 9 ; for biology and also for engineering, 6 and 4 ; and for mathematics and astronomy, 3 and 1 . In 1954 chemistry claimed 428 and in 1955 , 399 of the students receiving grants ; in physics the corresponding figures were 301 and 262; in engineering, 104 and 91; in biology, 97 and 107 ;

* Department of Scientific and Industrial Research. Report for the year 1954-55. Pp. 321. (Cmd. 9690.) (London: H.M. Stationery Office, 1956.) 78. $6 d$. net. in mathematics and astronomy, 60 and 86 ; in geology and mineralogy, 36 and 42 ; and in metallurgy, 26 and 23.

Expenditure of $£ 926,971$ gross or $£ 556,435$ net on the National Physical Laboratory was slightly more than in 1953-54 ( $\$ 513,049$ net), and this is true of expenditure on all branches of the Department's activities, except fire research, which decreased by $£ 2,922$ to $£ 22,433$; the increase on 1953-54 was, in general, about 10 per cent, apart from the contributions to European Nuclear Research, which

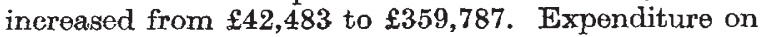
mechanical engineering research only increased, however, by $£ 1,154$ to $£ 315,561$. Net expenditure under the other major headings in 1954-55 was as follows, the increase over 1953-54 being given in brackets: building research, $£ 453,049(£ 41,455)$; food investi-

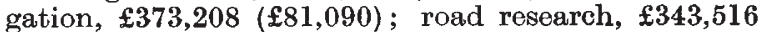
$(£ 37,984)$; fuel research, $£ 270,419$ (£23,535); geological survey and museum, £223,410 (£12,670); chemical research laboratory, $£ 136,350$ (£11,997); forest products research, $£ 116,487(£ 15,235)$; radio research, $£ 107,298$ ( $(12,901)$; hydraulics research, $£ 76,169$ (£14,607); water pollution research, $£ 74,321$ $(£ 11,648)$; pest infestation, $£ 68,145(£ 9,388)$; headquarters administration, etc., $£ 247,915$ (£27,536).

The contribution to the European Organization for Nuclear Research was increased to $£ 520,000$ in the 1955-56 estimates and further to $£ 930,000$ in those for 1956-57, while of the grants for special researches some $£ 250,000$ of the total $£ 315,425$ is for support of nuclear physics research in universities. This total was increased to $\$ 422,200$ in the $1955-56$ estimates and to $£ 497,000$ in those for 1956-57. These grants were provided for the installation and operation of the large particle-accelerating machines for research in nuclear physies in the Universities of Birmingham, Cambridge, Glasgow, Liverpool and Oxford, and the Advisory Council has endorsed the recommendation of the Nuclear Physics Committee for supplementary grants of $£ 7,720$ to the University of Glasgow and $£ 14,200$ to the University of Liverpool. A grant of up to $£ 82,000$ to the University of Manchester for the installation of a $6-\mathrm{MeV}$. Van de Graaff generator for research on nuclear structure has also been recommended by the Advisory Council.

Although the European Organization for Nuclear Research receives the major part of the Department's contribution to international co-operation, developments during the past year in desalting brackish waters have provided an interesting example of the difficulties as well as the possibilities of international co-operative research. A working party concerned with this subject, after considering a report on existing and potential processes for desalting, recommended that meetings should be called by the Netherlands to discuss electrodialysis with ion-exchange membranes, by the United Kingdom to discuss the prevention of scale formation in distillation equipment, and by France (in Algeria) to discuss solar distillation and certain aspects of ion exchange. Out of these meetings during the current year has come an agreement signed by Algeria (for France), Australia, South Africa, the Netherlands and the United Kingdom, 
under which, in return for a share of the development costs, the United Kingdom will have a voice in the development of the process of electrodialysis with ion-exchange membranes in the Netherlands and rights under Netherlands patents. Under a less formal agreement on scale-prevention work, the Department has contributed funds to permit expansion of the existing Admiralty research group, and the Netherlands have provided an additional research worker for the team.

\section{Government Establishments}

The Advisory Council's report refers again to the urgent need for a new Fuel Research Station and, as a prelude to planning a now station, has reviewed the policy which should govern the future work of the Fuel Research Organization. As a result, the Council has recommended that the Fuel Research Station should maintain its position as a national centre for the study of fuel problems free from political considerations and pressure of sectional interests; that the Station should aim at becoming the central organization in Britain for long-term basic research on fuel; and that it should not usually undertake applied research beyond the stage at which this can properly be transferred to other organizations engaged on fuel research. On this basis, it recommends construction of a new Fuel Research Station as a matter of first priority, and it is understood that the Ministry of Fuel and Power is in broad agreement with this policy and that the Committee of the Privy Council for Scientific and Industrial Research has adopted these recommendations.

About one-fifth of the total effort of the Station is now applied directly or indirectly towards reducing pollution of the atmosphere by the treatment and utilization of fuels and their products. Semi-automatic equipment for the elimination of smoke has been devised and tested on the Lancashire boiler at the Research Station with satisfactory results, and attention is also being given to coal-fired and oil-fired central-heating boilers with the object of increasing efficiency while decreasing emission of smoke. Work on the removal of oxides of sulphur from boiler flue gas by the use of ammonia has shown that by working. the process in two or more stages the sulphur can be recovered as ammonium sulphate with an efficiency of 96 per cent and loss of only 3 per cent of ammonia, and as a result of these experiments the Central Electricity Authority is erecting at the Nottingham generating station a pilot plant to treat 2 million cubic feet of flue gas per hour. After examining the fluidized catalyst process for the Fischer-Tropsch synthesis, attention has been given to the 'liquid phase' or slurry process, in which synthesis gas is bubbled through a suspension of powdered catalyst in heavy oil or molten wax ; and studies continued of the changes occurring in residual fuel oils on storage that makes them difficult or impossible to pump, with the view of devising a test that will make it possible to predict the behaviour of a freshly prepared oil. Examination of the industrial processes to which coal is submitted indicated that on carbonization of coals containing $6-10$ parts of germanium per million, up to 90 per cent of the germanium remains in the coke, and that the germanium contents of the dusts collected in heating-flues of the cokeburning producer of a coal carbonization plant rose to a maximum of three per cent in the recuperator.

The research stations with the work of which the Advisory Council's report is this year particularly concerned are the Fire Research Station and the Forest Products Research Laboratory. Both were visited by the Advisory Council, which was well satisfied with what it saw. It is convinced that the Fire Research Station is a continuing success. Although administered in detail as a government research establishment, it is a joint organization controlled by the Department and the Fire Officers' Committee, each contributing one-half of the running and capital costs. Under a new agreement recently concluded between the partners, the current annual expenditure will be increased from just under $£ 90,000$ to a maximum of $£ 125,000$, and the non-industrial staff will be gradually increased from just under 80 to more than 100. Extensive new buildings and equipment are to be provided at a cost of up to $£ 365,000$, and one of the now buildings, towards which and towards the general site the Fire Service Research and Training Unit has made a grant of

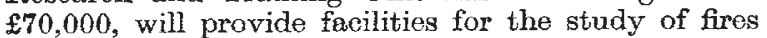
in large-scale models under controlled conditions. Work during the year has included an inquiry into the effect of heat on various types of high-tensile steel used in the construction of pre-stressed concrete, and the development of a new roof test and a new test for combustible wall linings; and a committee has been established to advise on a research programme on industrial fires and explosions.

Some 35 per cent of the staff effort at the Forest Products Research Laboratory (and also at the Building Research Station) is at present devoted to advisory and related work-a proportion which the Advisory Council regards as too high, and it hopes that the industrial research organizations will in future relieve the Laboratory increasingly of this type of work, leaving it freer to conduct more fundamental investigations. In particular, the Research and Information Committee of the Furniture Development Council and the Research and Development Committee of the Timber Development Associa. tion are expected to assume increasing responsibility for applied research in this field. Work during the year has included experiments with growing English ash which indicated that the degree of lignification of the fibre walls (which affects the strength of wood) is at least partly controlled by the illumination received by the leaves. A series of tests of the moisture gradient of wood carried out over a year indicates that where, as in boats or vats, the wet face cannot be painted, the dry face should also receive no paint, or at most only a thin pervious coat. Estimates of the strength of laminated timber have been extended to the study of beams from two different species, and research is being carried out on the permeability of woods to liquids and gases, on the factors that govern the susceptibility of various zones of Corsican pine to infestation by the furniture beetle and the house longhorn beetle, and on the bending vibration and damping of wooden beams and rectangular plates.

The proposals for the organization of practical trials in collaboration with the National Federation of Building Trades Employers met with a good response from the members, and a series of trials with aerated mortars has been completed, while the Building Research Station has also made good progress in developing a process for the production of light-weight aggregate from pulverized fuel ash. In designing large rigid frames, the main problem is to find a method which is sufficiently accurate while avoiding heavy design costs. It has now been shown 
that the behaviour of a frame to be designed can be deduced by reference to an idealized substitute frame which has already been analysed, and a new method of design for stanchions is being developed which will lead to further economy. Particular attention is being paid to the problem of measuring the stress in the linings of deep tunnels in clay and, as a result of the work on schools which has continued for some five years in collaboration with the Ministry of Education architectural development team and the Hertfordshire County Council, a body of essentially new information has been made available to designers, in terms of which they have been able to plan for fuel economy and design economy in schools.

Commenting on the work of the Chemical Research Laboratory, the Advisory Council expresses the opinion that the present programme of the Laboratory is well chosen and that, although the Laboratory's work on semi-permeable membranes, including membranes with ion-exchange properties, is limited, it has already made important contributions and should be continued and if possible extended. During the past year the trades concerned have been steadily brought into closer contact with the preparation of the Food Investigation Organization's programme and its work and, in the Fish Division in particular, close liaison has been effected with the White Fish Authority and the Herring Industry Board. The trawler Northern Wave has been chartered for a joint experiment in freezing at sea on a commercial scale, and special attention is being given to research on smoke-curing with the view of developing more convenient, controllable and economical procedures and of producing cures of white fish and herrings of consistently high average palatability and keeping quality. Plans have been drawn up for an experimental unit to be attached to a now centralized abattoir, and studies of fresh and frozen beef have continued. Recent storage trials have indicated that pears could be kept for longer periods at $30-31^{\circ} \mathrm{F}$. without suffering low-temperature injury, and work is also being continued on the effect of field factors on the chemical composition and storage life of apples. A coating of sulphonated polystyrene on diatomaceous earth has proved valuable in the chromatographic purification of insulin and a similar method has been developed for purifying meat myoglobin.

The Geological Survey has made continuous progress since the War with the primary six-inch survey, which is the basis of all Geological Survey work, and with the first six-inch re-survey of areas of economic importance ; it has also re-published ninety-two oneinch to the mile maps in colour-printed editions and extra editions of ten other maps printed to show solid geology only, making a total of 102 . But only four of the twenty-four quarter-inch geological maps of England and Wales have been re-published and nineteen of the sixty-two one-inch sheets of Scotland, with fourteen additional sheets showing drift geology. All ten of the seventeen quarter-inch geological maps of Scotland published before the War have been reprinted. The Geological Survey has also statutory obligations under the Mining Industry Act (1926) and the Water Acts of 1945 and 1946, while the Museum of Practical Geology, which again had a record number of visitors $(374,353)$, has acted as a study centre for geological research and exhibition of collections of minerals, gem-stones, rocks and fossils. During 1954, 270 square miles in Great Britain were covered by primary six-inch survey, and 253 square miles, including 75 square miles in Northern Ireland, by revision survey. Boreholes drilled during recent years continued to provide much material calling for specialized petrological investigation, and during 1954 more than eight hundred boreholes were notified to the Geological Survey under the terms of the Mining Industry Act and more than $300,000 \mathrm{ft}$. of strata were examined, identified and described. The Survey itself is drilling four boreholes in the Ashover district northeast of Matlock to ascertain the sequence and structure of the Millstone Grit and higher parts of the Carboniferous Limestone between the Derbyshire coalfield and the limestone country west of Matlock. The task of encouraging the search for the mineral raw materials necessary for the Atomic Energy Authority's programmes remains with the Atomic Energy Division of the Geological Survey, and besides further searches for uranium, attention is being given to a search for thorium deposits and to the development of new methods of geophysical and geochemical prospecting, particularly to fundamental research as to the most profitable lines for conducting geological exploration.

The work of the National Physical Laboratory and the Chemical Research Laboratory for the period have been reviewed in these columns fairly recently, so no more need be added here than that the Digital Electronic Universal Computing Engine (Deuce) was installed early in 1955 , and the construction of the final Automatic Computing Engine started. The High Temperature Fatigue Laboratory has now been transferred to the Mechanical Engineering Research Laboratory, the staff of which increased by 13 per cent during the year. Two further symposia, dealing with precision electrical measurements (November 1954) and boundary layer effects in aerodynamics (March 1955), have been held in the National Physical Laboratory.

The first stage of the main hall of the Hydraulies Research Station was completed in January 1955 and arrangements have been made with river boards and coast protection authorities to collect data on beach movements and all matters bearing on coastal protection; analysis of these observations will provide valuable information on long-term trends of erosion or accretion. The investigation into the behaviour of storm surges in the Thames Estuary has been extended to examine the effect which a barrage would have in reducing storm surges of various magnitudes, and the large model of the River Thames is being used for investigating the general pattern of estuarine circulation and its relation to the tendency for serious silting to occur in the so-called "Mud Reaches" immediately downstream of the Royal Docks. A model of the tidal reaches of the River Trent is being constructed. A second model has been built in connexion with the Severn River Board's scheme for the relief of flooding on the River Severn; this includes 24 miles of the river downstream from Shrewsbury to Buildwas, and it is being used for ensuring that the reduction of floods in the neighbourhood of Shrewsbury will not lead to more serious flooding elsewhere along the river. Basic experiments in the $54-\mathrm{ft}$. wave tank have indicated that a screen of spaced piles offshore from a sand beach did not cause the beach to build up but halted or almost halted erosion, and two-dimensional wave tests have been carried out for the Kent River Board on a model of a section of the proposed Dymchurch sea wall. The proposed design of a new harbour to 
be constructed at Tema on the Gold Coast is being investigated in Wave Basin No. 2.

Biological research in the Pest Infestation Laboratory included field-work on residual populations of insects in farm buildings, in an old watermill and in disused dock storage sheds. Research on grain storage was largely confined to the experimental storage of damp grain in airtight silos; that on insecticides included a new method for the chemical assay of pyrethrins, the control of bean weevils with insecticidal dusts, the mechanical protection of goods from infestation by sheeting, and the relative susceptibility of different insect species to pyrethrins. Long-range biochemical work was concerned with the nature and significance of insecticide residues in foodstuffs and mechanisms of insecticidal action.

In the Radio Research Organization the main emphasis continued to be on the factors which affect radio waves during transmission between the transmitting and receiving stations; but the importance of the work on semiconductors and on ferromagnetic materials is also stressed, the former being concerned with noise generation in germanium and components made from it and with measurements on transistors. In the field of navigational aids, the main interest is in low-frequency and very low-frequency positionfixing applications and, at higher frequencies, in radio direction-finding.

A main group of researches carried out by the Road Research Laboratory seeks to provide road engineers with the basic information needed for decisions as to the most satisfactory and economical types of road construction for particular conditions of soil, traffic and climate; and the Ministry of Transport and Civil Aviation's programme of new road construction will provide the necessary opportunities for full-scale experiments. A scheme has been introduced by which the results of research are embodied in agreed specifications for use on selected sites under conditions of good normal commercial practice. Evidence is accumulating that the separation of motor traffic from other road users decreases accidents, and a study has been made of eighty-six sites reported as the scene of repeated skidding accidents. The Laboratory's work on non-destructive tests for measuring the strength of concrete by an ultrasonic pulse technique has been summarized and the equipment required is now being manufactured.

The new Water Pollution Research Laboratory at Stevenage was officially opened on June 20, 1955, and investigations in progress include a detailed study of the effects of pollution on rivers and estuaries, fundamental work on processes of sewage treatment and the investigation of methods of treating industrial waste waters. Progress was made in studying the oxygen balance of the Thames Estuary and in attempts to predict the effect of polluting discharges on the content of oxygen in the estuary water. Observations on the effect of sewage effluent on the River Colne near Watford have been completed, and tests with seven popular proprietary washing powders indicated that 50 per cent of rainbow trout were killed in about seven days in a solution containing the equivalent of rather less than 6 p.p.m. sodium dioctylsulphosuccinate.

The work of the Intelligence and Information Division of the Department is mostly directed towards the improvement of industrial productivity, and altogether a programme of twenty-nine projects concerned with human factors in industry and costing more than $£ 155,000$ from Conditional Aid Funds is guided by the two joint committees of the Department and the Medical Research Council and serviced by the Division. Most of the projects are being carried out by the universities, independent research institutions or research associations; but one concerned with problems of work study, including those of introduction, such as the reasons for suspicion and resistance, the assessment of results in terms of the impact on efficiency and human relations within firms, and problems of continuing application, is being undertaken within the Division. Work has continued on the sample survey of research expenditure of private industry, and an economist was appointed to help the Food Investigation Organization and the Pest Infestation Laboratory assess the economic relevance and application of their current work. The Industrial Operations Unit has demonstrated the value of a more systematic study of industrial operations, particularly of improved methods of planning and controlling work, and a survey has been initiated of technical developments leading to automatic processes in industry and of the broad economic and social implications of these developments. During the year, following successful pilot-plant trials of a suggestion that effluents might be treated with ammoniacal liquors from gas works to produce ammoniacal sulphate and a hydrated iron oxide, the Gas Council decided to erect a full-scale plant. The iron oxide will be mixed with peat and used for sulphur recovery, and besides reducing imports of bog iron ore the new process will reduce the demand of the gas industry for sulphuric acid.

(To be continued)

\section{CHROMATOGRAPHY AND PARTITION OF CELLS AND CELL FRAGMENTS}

By PER-ÅKE ALBERTSSON

Institute of Biochemistry, University of Upsala

$\mathrm{T}$ HE study of isolated cell particles has given much information about the organization of the cell. The method which is generally used for fractionation of the particles from a homogenate is differential centrifugation. In that method, differences in the sedimentation velocitios of the particles are utilized for their separation, and differences in sedimentation velocities depend mainly on differences in size, density and form of the particles. Ultracentrifugation in density gradients has also been used for the same purpose. Here the difference in particle density is the determining factor. It should be possible, however, to utilize differences in other properties, too; for example, physical and chemical properties of the surface and the electrical charge of the particles. 